August 2010

\title{
The Czech Republic on the UN Security Council: The Rwandan Genocide
}

Karel Kovanda

Follow this and additional works at: https://digitalcommons.usf.edu/gsp

\section{Recommended Citation}

Kovanda, Karel (2010) "The Czech Republic on the UN Security Council: The Rwandan Genocide," Genocide Studies and Prevention: An International Journal: Vol. 5: Iss. 2: Article 7.

Available at: https://digitalcommons.usf.edu/gsp/vol5/iss2/7

This Articles is brought to you for free and open access by the Open Access Journals at Digital Commons @ University of South Florida. It has been accepted for inclusion in Genocide Studies and Prevention: An International Journal by an authorized editor of Digital Commons @ University of South Florida. For more information, please contact digitalcommons@usf.edu. 


\title{
The Czech Republic on the UN Security Council: The Rwandan Genocide ${ }^{1}$
}

\author{
Karel Kovanda \\ Deputy Director-General of External Relations, European \\ Commission, Brussels
}

\begin{abstract}
The Rwanda civil war that in 1994 degenerated into a slaughter of the country's Tutsi, amounting to genocide, was possibly the world's most devastating bloodbath of the 1990s. In 1994, the newly formed Czech Republic took up its place as a non-permanent member of the UN Security Council; Karel Kovanda was the Czech Ambassador at the time. Drawing on internal documents of the Czech Foreign Service and on his own private notes, as well as on a wealth of published information, Kovanda details in this personal memoir the step-by-step evolution of the Rwandan tragedy as he and his delegation perceived it, and the Czech reaction to it. He repeatedly highlights the information gap: on the one hand, insufficient and biased information provided by the UN Secretariat; on the other hand, the detailed, accurate, and timely information his delegation received from NGOs. Kovanda estimates that during the first weeks, the Security Council gave perhaps $80 \%$ of its attention to the civil war between Rwandan government forces and the Rwandan Patriotic Front (RPF) and 20\% to how to handle the difficult position of UNAMIR, the peacekeeping operation then on the ground in Rwanda. Only after weeks of delay did the Security Council even start to come to grips with the ongoing genocide-a term that Ambassador Kovanda was the first to employ publicly in an official UN meeting. While focusing on Rwanda proper, Kovanda also explains and describes the sometimes little-known mechanisms that play a role in the day-to-day workings of the Security Council: the role of the UN Secretariat, informal consultations, groupings of Security Council members, and so on.
\end{abstract}

Key words: Rwanda, genocide, Czech Republic, UN Security Council

\section{Introduction}

Apart from its five permanent members, the UN Security Council (UNSC) has ten non-permanent ones, elected by the UN General Assembly for two years-five one year, the other five the following year. In the autumn of 1993, a sharp electoral battle involved the Czech Republic: after only a few months as an independent country (following the division of Czechoslovakia on 1 January 1993), the Czechs were fighting for UNSC non-permanent membership against Belarus. In June 1993 I assumed the position of Czech Ambassador-Permanent Representative to the UN, and was directly in charge of our electoral campaign.

In the event, we won the elections, in October 1993, together with Argentina, Nigeria, Oman, and Rwanda. These five countries would be joining the five other non-permanent members, carryovers from the previous year: Brazil, Djibouti, New Zealand, Pakistan, and Spain.

Karel Kovanda, "The Czech Republic on the UN Security Council: The Rwandan Genocide." Genocide Studies and Prevention 5, 2 (August 2010): 192-218. (C) 2010 Genocide Studies and Prevention. doi:10.3138/gsp.5.2.192 
A lot has changed in the work of the UNSC since the 1990s: by and large, its work has become more scripted and formal. But as the Czech Republic joined the Security Council in 1994, managing its work was a matter for its president. He or she scheduled and chaired the public, formal meetings that we know from TV. In addition, however, the president organized and chaired so-called informal consultations of the UNSC. It was actually these consultations that occupied most of the president's time and demanded most of his or her energy. At the time, they took place almost daily, sometimes even several times a day; they were held behind closed doors, in a separate chamber of the UN Secretariat to which non-members of the UNSC, never mind journalists or other members of the public, had no access. But it was precisely during these informal consultations that everything, even the smallest matters, was decided. Everything that later saw the light of day at formal meetings (except for the actual statements of countries, formally called the "explanation of the vote") would be agreed here beforehand. This was where the text of every document, often down to the shade of meaning of every word in every UNSC resolution, every presidential statement, was negotiated, even fought over-usually by experts, that is, diplomats specializing in the given subject matter, but from time to time by ambassadors themselves. In this forum, ambassadors would also discuss a variety of other issues that never ended up being debated publicly. This was where the Security Council did its real work, whereas its formal meetings, then as now, resembled a theatre piece with proceedings scripted in advance.

The office of president rotates monthly, following the name of the country, in English alphabetical order. The president occupies the seat at the head of the oval conference table, and on the first of every month, the 15 UNSC members move one seat to the right. In December 1993, the top seat-the presidency-was occupied by China. Consequently, in January 1994, the chairmanship fell to the newly elected Czech Republic. And straight away, in January, we got a foretaste of what was to happen in Rwanda several months later.

I will return to these January matters. The critical chapter of this story, however, started only three months later, in April 1994. That month, the Security Council was chaired by Ambassador Colin Keating of New Zealand.

\section{UNAMIR}

During the first week of April, we were dealing with situations in Bosnia and Herzegovina, a permanent fixture on the UNSC agenda; with issues in Georgia, Iraq, El Salvador, and Israel; and with the Libya-Chad relationship. Another of the many questions was that of extending the mandate for one of the numerous peacekeeping operations (PKOs) that the UN had stood up in various parts of the world, namely the UN Assistance Mission for Rwanda (UNAMIR).

A civil war among various factions had been underway in Rwanda for several years already. ${ }^{2}$ In the autumn of 1993 , the UNSC decided to organize this peacekeeping operation, which was to oversee the fragile truce between the antagonists. The UNSC had agreed to create it on 5 October 1993, in its Resolution No. 872. ${ }^{3}$ UNAMIR was to promote the rapprochement of the belligerent parties. One party consisted of the Rwandan government institutions, headed by President Juvénal Habyarimana, and their armed forces, both military and paramilitary. Most of these were Hutu. They were opposed by the so-called Rwandan Patriotic Front (RPF), consisting of the minority Tutsi people. ${ }^{4}$ The hard core of the RPF consisted of Tutsi who had escaped Rwanda for neighboring Uganda in 1959, when an earlier wave of interethnic slaughter engulfed the country. Still, in 1993, under pressure from the 
international community, both parties managed to sign a series of agreements, the Arusha Accords (named for Arusha, Tanzania, where the accords were signed). ${ }^{5}$ UNAMIR was to keep an eye on the parties' actually fulfilling these agreements.

UNAMIR was not very big, and its members were lightly armed; their mandate was rather weak. All this followed from the view of the UN Secretariat (with which the Security Council agreed at the time) that the toughest part was to get the parties to actually reach an agreement; putting it into effect was not expected to be too much of a problem. But just a few short months after authorizing the formation of UNAMIR, we were arguing as to whether and under what circumstances its mandate should be extended.

Arguing over the conditions of extending a mandate had its own well-established framework: Will we agree to a shorter or a longer extension? Should we threaten to end the operation if the antagonists refuse to cooperate? The UN Secretariat recommended extending the mandate by six months, but the United States, for example, wanted the shortest possible extension-they'd be happy with one month, perhaps two, OK: let's make it three. It took a lot of work for the UNSC to finally agree, in resolution $909 / 1994,{ }^{6}$ on a four-month extension, with a proviso that after six weeks, we would evaluate how the situation in the country was evolving. The date was 5 April 1994.

\section{The Air Crash}

For the Security Council as a whole-and this was definitely true for the United States - the issue of PKOs was singularly affected by a major debacle in Somalia. In October 1993, some six months before the events I am leading up to, the United States lost eighteen of their soldiers there, and the whole nation was enraged at TV shots of the soldiers' bodies being dragged through the streets of Mogadishu to the exuberant joy of bystanders. From that moment on, the United States was particularly perspicacious when it came to PKOs in general, and particularly those in which they participated themselves. The post-Somalia discussion culminated in Washington in Presidential Directive No. 25, which specified US policy concerning these operations and outlined certain criteria that would guide the decision as to whether to support this or that UNSC PKO and whether or not to participate. ${ }^{7}$ Madeleine Albright has written that its objective was to "to put America squarely on the side of strengthening UN peacekeeping operations," but "with the understanding that ... we would henceforth make the chain of command clearer and insist that such missions be ... preceded by a significant period of consultations with Congress." 8

In the event, Rwanda was to become the test case for how solid this policy was; for on 6 April, only a day after the give-and-take over extending UNAMIR's mandate ended, news arrived about a catastrophe at the airport in Kigali, Rwanda's capital. Two presidents lost their lives in a plane crash: Juvénal Habyarimana of Rwanda and Cyprien Ntaryamira of Burundi.

It wasn't clear what had actually happened: one wondered, did the plane crash, or was it shot down? Was it an accident, or an assassination attempt? To one person, however, the answer was completely clear, before any investigation was so much as launched: Rwanda's permanent representative to the UN, Ambassador JeanDamascène Bizimana. Coincidentally, Rwanda, like the Czech Republic, was a new member of the UNSC, never mind that the country was engulfed in a civil war and that it was the subject of the UNSC's close attention. Bizimana had no doubts-and made no bones about his opinion-that what had occurred was an act of terrorism 
in which the RPF was the ultimate villain. Ambassador Jean-Bernard Mérimée of France also argued from the very first moment that the event was a terrorist attack. (The identities of those actually responsible for the plane crash were, to my knowledge, never determined, although responsibility of the RPF cannot be excluded.)

\section{Information}

The UNSC receives its information from the UN Secretariat, the apparatus that resides in that enormous matchbox which we all recognize from any number of images as the main UN building in New York, and which is headed by the secretarygeneral of the UN (UNSG). At the critical moment, the Egyptian Boutros BoutrosGhali was UNSG. The Secretariat, in turn, receives reports from its own people in the field. Information gathered in this way would be elaborated as formal Reports of the UNSG, which constitute the basis for any discussion of the UNSC, on any issue, of any territory.

At the critical moment, there were two people in Rwanda directly subordinated to the UNSG. One was his so-called special representative (SRSG), the highest civilian UN official in the country, a certain Dr. Jacques-Roger Booh-Booh, formerly the foreign minister of Cameroon. I never knew much about him; for example, he never showed his face in New York to report personally to the Security Council, which was the standard practice of other SRSGs the world over. I had heard, however, that he was close friends with President Habyarimana, and one might well have wondered about his objectivity.

The other UN official who fed the UN Secretariat with information was the Canadian General Roméo Dallaire, commander of UNAMIR. ${ }^{9}$

Thus, it was on the basis of information from these two officials that the UN Secretariat prepared its Rwanda reports, which, in turn, served as the bases for UNSC deliberations. The Czech delegation, like those of a number of smaller countries, didn't actually have in hand any information apart from these reports. The nearest embassy we had (and have to this day) was in Kenya, and Czech diplomats there had precious little opportunity (or reason) to report first-hand from Rwanda. Of course, major powers had their own additional sources of information, aside from the UN Secretariat's briefs. Of the UNSC members, both the United States and France actually had their own embassies in Kigali.

\section{Early Czech Involvement}

From the Czech point of view, PKOs were important, particularly where our own soldiers or observers were involved. But although during the 1990s Czech personnel had been stationed in various places in Africa, including Angola, Mozambique, Liberia, and Somalia, none were stationed in Rwanda as part of UNAMIR. Rwanda was on the periphery of Czech interests; we had no historical interests, no economic interests, no interests connected with our own personnel there.

I didn't understand the Rwandan situation very well. After all, several civil wars were going on in Africa at the time. Nevertheless, my very first public statement in the UNSC coincidentally concerned precisely this topic, inasmuch as, in January 1994, the UNSC was deciding on the first extension of UNAMIR's mandate. The matter was rather foreign for the Czech Republic, and, personally, I didn't study it carefully either. Rereading the statements of other UNSC members, ${ }^{10}$ one gets the sense that no one, certainly not me, had any foreboding of the horrors that were to engulf the country within three short months. In fact, before I took up the UNSC 
presidency in January, I had followed well-established custom by starting off with a round of individual consultations with every other UNSC member, inquiring as to how each evaluated the situation in various hot spots of the world; with respect to Rwanda, I reported the findings as follows: "According to most of the delegations, the peace process is progressing rather well. Nigeria sees positive signals that offer a chance to resolve the conflict without major delays and take it off the Council agenda altogether."11

\section{Forebodings}

And yet some-although beyond the UNSC circuit-did have their forebodings. One of them was Claude Dusaidi, an RPF representative working the corridors of the UN, who would share his views of Rwanda developments with all who would listen. As early as 7 January, he paid me a visit, not as the Czech Ambassador, for we really were too insignificant-certainly as far as matters in Rwanda were concernedbut as the January UNSC president. He explained that the fulfillment of the Arusha Accords was in jeopardy. President Habyarimana had, for example, refused to form a provisional government, which the accords foresaw for December 1993, and instead had prepared a list consisting exclusively of his own people, completely disregarding the views of other political forces. I informed the Czech Foreign Ministry, as well as my colleagues on the Security Council, about Dusaidi's visit; informally, I also distributed a letter that he gave me, simply by passing copies around the table. ${ }^{12}$

Another person who had a horrific premonition-or, rather, horrific informationwas General Dallaire. On 11 January 1994 he sent a certain critical telegram from Kigali, in which he described what he had learned from one of his sources: that Hutu paramilitary militias were gathering weapons and compiling lists of Tutsi in order to kill them all off at a suitable moment. Dallaire asked for permission to intervene, for example, to take over illegal weapons storage areas. ${ }^{13}$

The Security Council never learned about this telegram. And the UN Secretariat did not give Dallaire the go-ahead to intervene.

The Dallaire telegram is generally considered a key juncture, an opportunity for the international community to forestall the Rwanda catastrophe. If only we had known ... A number of journalists have asked me over the years whether the UNSC would have acted differently, if it had known ... It serves as an impulse to reflect about "alternative history." But even though such reflections are usually barren, one might quite soberly say this much: If the Security Council had been familiar with the telegram, it would at least have had a chance to do something. At least a chance.

\section{A Detour: The Story of the Dallaire Telegram}

But the Security Council was not familiar with the telegram. The telegram itself had a peculiar fate. The UN Secretariat-either the Department of PKOs, headed at the time by Kofi Annan, or the Department of Political Affairs, headed by Marrack Goulding, a British official-had obviously underestimated its significance, and did not inform the Security Council about it. ${ }^{14}$ "Such situations and alarming reports from the field, though considered with the utmost seriousness by United Nations officials, are not uncommon within the context of peace-keeping operations," wrote Boutros Boutros-Ghali in his foreword to the UN's Rwanda sourcebook. ${ }^{15}$

But much later, long after the catastrophe was over, the UN Secretariat realized that they perhaps should have mentioned the telegram to the Security Council: in his foreword to the sourcebook I've been quoting, Boutros-Ghali averred that 
Chinmaya Garekhan, his special advisor, informed the Security Council on 12 January "on the reports that had been received from UNAMIR."16 I found this strange: after all, I had chaired the Security Council during that time, and was sure that I would have remembered discussing such a telegram, or even receiving information about it, if only because my meeting with $\mathrm{Mr}$. Dusaidi a few days earlier had sensitized me to the Rwanda problématique.

In December 1995, as my tenure on the UNSC was drawing to a close, I therefore wrote a letter to the UNSG. I noted that I remembered the matter differently, and how should we explain that we have such different recollections of the circumstances of that fateful telegram? The UNSG invited me to a meeting but held his own. Mr. Garekhan, an Indian who regularly represented the UNSG at informal Security Council consultations and conveyed to the Security Council on his behalf information, was present as well. He made the point that "for better or worse, no reports are written from informal consultations," so it would no longer be possible to ascertain what actually happened. We ended up agreeing to disagree, simply noting our differing recollections. ${ }^{17}$

However, reports from Security Council consultations are indeed made. It is well known that the UNSG has his people write fairly detailed and unsparing minutes: if someone makes a stupid comment, that's how it is described. These are confidential reports, however, strictly for the needs of the UNSG and his immediate entourage, and only rarely do they seep out beyond this narrow circle of UN officials. ${ }^{18}$ Thus, in his discussion with me, Garekhan was not quite candid as far as the existence or not of such reports is concerned. ${ }^{19}$ And as for the substance of the matter, when an independent commission dealt with the failure of the Security Council in Rwanda, it criticized the Secretariat for not having informed the Security Council. ${ }^{20}$

One wonders, of course, how the Secretariat itself perceived the situation in Rwanda. As I have pointed out above, it was receiving two sets of reports, one from General Dallaire and one from the SRSG. When these two lines of reporting disagreed (and they allegedly disagreed fairly frequently), the Secretariat and the UNSG were inclined toward the reading their "own" man provided. In a personal conversation in April 2004, General Dallaire told me that "they simply took me first as a soldier, and second as a fellow who's in Africa for his first time and doesn't understand anything."

\section{Murders in Rwanda, Uncertainty in the Security Council}

Let's return to events in April 1994. As soon as the two presidents perished in the plane crash, a terrifying wave of murders of Tutsi erupted throughout Rwanda. It was not spontaneous, it was not coincidental, it was not chaotic; this was a wave of systematic murder, carefully prepared in advance. Just as General Dallaire had predicted, it followed lists of names, addresses, Kigali license plates of Tutsi-owned cars, using weapons that Hutu had been accumulating for some time. The most awful behavior among Hutu was exhibited by the Presidential Guard and by specific organized militias and groups, the worst of which was the paramilitary Interahamwe. Within twenty minutes after the crash, roads in Kigali were blocked. Interahamwe personnel checked documents of passengers in all vehicles, and those whose documents were marked "Tutsi" were dragged out and killed. Several thousand Tutsi were murdered within the first few hours.

As the world eventually learned to its horror, this wave of murders (called "work" by Hutu officials) continued unabated for days and entire weeks. It was significantly spurred on by the firebrand broadcasts of Radio-Télévision Libre des Mille 
Collines. Tutsi were being murdered, but-especially during the first few days-so were moderate Hutu politicians, including those who were to form the Arusha-agreed government, including the prime minister-designate, Agathe Uwilingiyimana.

At the same time, the front in the civil war moved. The RPF-naturally-did not intend to stand with folded arms and stick to the Arusha-agreed truce while armed Hutu were slaughtering their fellows. In my report to Prague, I described the activation of the supposedly demilitarized Tutsi as "very disturbing," 21 which indicates just how little I understood the situation in its first moments. On 7 April, the Security Council issued a Presidential Statement ${ }^{22}$ that emerged from the workshop of France and non-aligned UNSC members. It expressed its "regret" over the plane crash and "the ensuing violence." It "strongly condemned" attacks against government officials, against "many" civilians, and, "in particular," against UN personnel. It appealed to all sides in the conflict to "maintain the positions they held before the incident" (i.e., before the plane crash) and "in particular to respect the cease-fire." These last formulations were directed against the RPF and against the Tutsi, but I clearly didn't realize that at the time.

In the following days, the Security Council met, and met, and met again, but didn't manage to come to an understanding of the situation. On 8 April, I conveyed to Prague information from the Secretariat: "the situation is unclear." 23 The Security Council didn't understand the Rwanda situation-or didn't want to understand it? The UN Secretariat didn't forward much information. Great Western powers seemed to have only a cursory interest in Rwanda. ${ }^{24}$ There is no doubt that they had their own information ahead of time. Two of them had embassies in Rwanda, and the Secretariat shared the contents of the Dallaire telegram with France and the United States (but only with them, and with Belgium). I had the intense feeling that the Security Council was rudderless. Usually, the role of the Security Council's intellectual leader, the one who could "see around the corner," was played by the UK's ambassador, Sir David Hannay. On this occasion, however, he didn't have much to go on: as I learned much later from a British Foreign Office official, he was allegedly receiving virtually no instructions from London (Britain had never had an embassy in Kigali before August 1994) except to follow the lead of French diplomacy.

It appeared as though permanent members of the UNSC were giving the wave of murders a wide berth, as though they didn't want to dirty their hands with it. After all, this was a domestic matter, not an international conflict, wasn't it? And domestic matters, civil wars, tribal conflicts and ethnic cleansing, as well as dictatorial regimes, suppressing basic human rights, and the like-none of this was in the mandate of the UN Security Council. The Security Council dealt with international peace and security; what didn't have an international dimension didn't belong on the UNSC's agenda, at least not technically.

One worry we did have: not the murderous rampage against the Tutsi, but the fate of foreigners in Rwanda and the role of UNAMIR. During the first hours of the bloodbath, berserk units of the Rwandan government army also butchered ten Belgian paratroopers who had been guarding the prime minister-designate. "Our boys" thus faced a clear danger, and there was not much UNAMIR, with its small numbers, light equipment, and weak mandate, could do. What to do about this? Strengthen UNAMIR? Withdraw it? Reduce it? And while France sent in a humanitarian mission to pull out foreigners (without making the slightest effort to protect their Tutsi collaborators or other people close to them), the Security Council spent endless hours discussing the UNAMIR problem. 
It was a problem indeed: UNAMIR was a peacekeeping operation, but the soldiers had deliberately been given a weak mandate and were only lightly armed. It might have been difficult for them to defend themselves against groups of murderous Hutu running amok and probably on drugs. And UNAMIR was paralyzed by the fate of their murdered Belgian comrades.

\section{The Belgian Withdrawal}

This incident formed the basis for the Czech evaluation of the situation as well. As a result of its losses, Belgium decided on 12 April to pull out its entire contingent from UNAMIR. The Belgian troops were the best of the lot, and had the best weapons. I got a call from Prague from Dr. Ivan Bušniak, who had taken over my previous job as director general for bilateral relations with Europe and North America. He informed me that Mr. Willy Claes, the Belgian foreign minister, had telephoned the Czech Ministry of Foreign Affairs and ended up talking to Ivan-coincidentally, neither the Czech foreign minister nor any of his deputies was available at the time. Claes informed Ivan about the Belgian pullout and recommended the withdrawal of the entire UNAMIR contingent.

Ivan was surprised that the Belgian minister would stoop to talk to a "mere" director general, a post two levels below his own. But this only indicated just how important this conversation was for Claes. I later learned that he called Argentina (another non-permanent UNSC member) as well, and I suspect that he called all UNSC member states. From the Czech point of view, the opinion of Belgium was of paramount importance: this erstwhile colonial power was linked with Rwanda by a thousand ties. ${ }^{25}$ Who better to understand the situation in the country than Belgium? I felt we could do much worse than follow Belgium's advice. Only later did I come to understand that Belgium's concern was not Rwanda, or UNAMIR, but rather camouflaging the precipitous withdrawal of their own contingent and the consequent weakening of UNAMIR.

\section{Groups of UNSC Members}

The situation in the Security Council was further obfuscated by the membership of Rwanda itself. The very fact that Rwanda was elected to the Security Council, or even that it had put itself forward as a candidate, was bizarre, given the civil war raging in the country, of which the Security Council was seized. That's the way the UN works, though, in many instances: non-permanent seats on the Security Council are reserved for individual regional groups of member states, according a requirement that is partly written, partly based on custom, and once the African regional group of members decided to support Rwanda's candidacy, there was not much anyone could do about it.

Ambassador Bizimana of Rwanda was a Hutu, and the situation was clear to him: everything was the fault of the Tutsi. Bizimana participated in the dealings of an informal yet very influential so-called Non-Aligned Caucus (NAC), which met behind closed doors before every session of informal consultations and coordinated its approach. At that time, other members of the caucus included Djibouti, Nigeria, Oman, and Pakistan. These countries continued to focus on the situation as they had known it during previous months - that is, on the civil war. Few gathered that in addition to the civil war between government forces and the RPF (the end of which was supposed to have been spelled out in the Arusha Accords), a completely new firestorm had erupted behind the line of conflict, that is, the mass slaughter of Tutsi who had nothing to do with the civil war. I recall that for Salim al-Khussaiby, the 
ambassador of Oman, an extremely friendly giant of a man, the key to stopping the slaughter amounted to restoring the cease-fire between the government forces and the RPF; he failed to realize that such a cease-fire would have helped only the Hutu, who would have one less worry on their minds while massacring the Tutsi, whereas the RPF would in effect be betraying their people if they did not seek to come to their rescue as fast as possible. On another occasion, Salim complained about "various individuals" who are tolerated in the UN corridors even though they have nobody's mandate to do anything-having in mind none other than Claude Dusaidi, the RPF representative, the very person who had informed me during my term as UNSC president in January 1994 about the problems besetting his country. Salim's inspiration was clear: these comments didn't germinate in his own head but, clearly, echoed the arguments that the ambassador of the Rwandan Hutu government must have been spreading among the non-aligned.

France played a particularly strange role. It had great influence over non-aligned members, both via Ambassador Bizimana of Rwanda and via Roble Olhaye, the ambassador of Djibouti. This very poor country on the Horn of Africa allegedly hosted French advisors directly in its Foreign Ministry, and on several occasions the French permanent representative, Jean-Bernard Mérimée, took the side of the murderers, overtly or covertly. One can only guess what was behind French policy. President François Mitterrand and his wife, and their relationship with the Hutu President Habyarimana, no doubt played a role.

French fears that Rwanda's membership in the Francophonie could be jeopardized played a role as well, inasmuch as the RPF Tutsi, who had spent decades in Uganda, spoke English. Yet I found it downright grotesque to hear Ambassador Olhaye, of all people, saying, "Those RPF people, why, they don't even speak proper French!" First, I would never consider anybody's language as an appropriate basis for making political decisions; and, second, I found it quite strange for such a scurrilous comment to come from Olhaye who, though from Francophone Djibouti, was never heard to utter a word except in English. Again, this argument did not come from his own head.

Apart from the permanent members and the non-aligned, there was a third group of Security Council members, "the leftovers," who were neither permanent members nor part of the NAC, and were therefore called "non-non." In 1994, the Czechs were part of this group, together with Argentina, New Zealand, and Spain. (I don't recall whether Brazil joined the non-aligned or the "non-non.") When it came to Rwanda, however, this group was truly non-aligned, truly not involved. None of us had any great-power ties with Rwanda, nor a colonial past, nor were we afraid to criticize its government, as was the case among the non-aligned, where solidarity, including false solidarity, often reigned supreme. And, unlike many nonaligned countries, we had no reason to fear that our criticism of the situation in Rwanda could boomerang against our own domestic policies; none of us had a Biafra in our recent history. In the following weeks it was precisely these countries, the "non-non" Security Council members, who pronounced themselves most clearly on the Rwanda tragedy.

\section{Better Information!}

What then should the Security Council have done? On 10 April I wrote to Prague that the trickiest discussion would concern the question of whether the Security Council should even continue to be involved with Rwanda. The argument in favor of involvement, I wrote, was "the alleged responsibility that the UNSC bears for 
Rwanda (or for its innocent civilian population)" and the argument that the situation there jeopardized the security of neighboring countries. ${ }^{26}$ Others would argue against involvement, on account of "this being a domestic matter of a country which the UNSC should not get involved with." 27 Four days after the plane crash, after four days of slaughter, the matter still wasn't clear to me, and I still wrote about "alleged" responsibility. This was the classic Security Council stance: getting involved in the domestic affairs of a country had once before not paid off-in Somalia. If the conflict at hand didn't have an unmistakable international dimension, we should leave the locals to fight it out amongst themselves, even if in the process they were to kill themselves off completely. In Rwanda, meanwhile, the number of dead had reached the tens of thousands.

We were not receiving much information from the Secretariat, and such information as we did receive was not accurate. Day after day, as the slaughter in Rwanda continued, we were dealing with the situation there only very superficially. According to the Secretariat, what was happening in Kigali was "armed combat among various factions." 28 What was really happening I realized only from an opinion piece in the New York Times by Frank Smyth of the NGO Africa Watch. ${ }^{29}$

I hadn't known of Africa Watch before, but it was one of the Helsinki Watch family of organizations, which I knew well: during the Communist era, Helsinki Watch had been very involved in defending Czechoslovak dissidents. There was therefore an a priori reason to trust the Africa Watch folks. But, more importantly, Smyth's article had an internal logic. Suddenly I had a eureka! moment; suddenly the scales fell from my eyes. Everything started making sense: both events in Rwanda itself and how to interpret the attitudes of individual UNSC members. Ten days had elapsed since the plane crash. The Security Council, meanwhile, was still in the throes of worry about the UNAMIR soldiers and the partial interests of some of its members, and continued to ignore the ongoing carnage.

Smyth argued that the slaughter was not accidental but managed. He explained that President Habyarimana had ruled through his Akazu clique and that slaughtering their opponents was the only way they could hold onto their twenty-one-year-old rule. Akazu needed weapons, but domestic legislation prevented Belgium, the old colonial power, from exporting weapons to war-torn countries; France, however, had begun military cooperation with Habyarimana in 1975. France was concerned with maintaining la francophonie in Rwanda. In addition, the presidents of the two countries (Habyarimana and Mitterrand) were friends. And France had assisted Rwanda in making a major arms purchase from Egypt_during the very period (1977-1979), as I learned later, when Egypt's Foreign Minister was none other than Boutros-Ghali.

Smyth was mentioned as the author of a study on arming Rwanda that had been published several months earlier. ${ }^{30}$ And suddenly I understood the peculiar game played by France in the Security Council, as well as the foot-dragging of the UN Secretariat (i.e., of Boutros-Ghali) in presenting the full picture of the horrors that were unfolding in Rwanda.

Seeking further information, I contacted Africa Watch directly and thus met one of the world's leading specialists on Rwanda, the late Alison Des Forges. We became fast friends, and in subsequent months she became the source of accurate, dependable information about the situation in the country. There was a chasm of difference between her information and that of the UN Secretariat. I therefore decided-for educational purposes, one might say-to invite her to explain the situation to some of my colleagues. 
And so it happened that on 18 April 1994, the Czech Mission to the United Nations hosted a very unusual meeting during which "small countries," nonpermanent UNSC members, had an opportunity to learn from reliable and extremely well informed, albeit informal, sources about the causes, origins, and course of the Rwanda catastrophe. Alison herself recalled this meeting as a quite extraordinary opportunity for her as an NGO representative to communicate directly with diplomats working on the UNSC. ${ }^{31}$

According to Alison's information, the murder mill in Rwanda was to start up again, in full force and even more intensively, on 8 May. She hoped that the UNSC would decide to send in soldiers who could protect and save the remaining Tutsi. I stripped her of the last illusions she may still have had concerning the UN's abilities when I pointed out that even if the UNSC were to decide on such an operation the following day, it would take weeks, even months, before member countries would offer contingents, before an operation could be organized, before it could actually be deployed in Rwanda. It broke her heart. Some of her friends were still in hiding in Kigali, and only a miracle could probably help them now.

\section{The Security Council on UNAMIR}

On 11 April, the Secretariat informed us that they were preparing a "long-term" study of UNAMIR's future. The alternatives would be based on developments in-country. These developments would either show improvement, in which case UNAMIR could stay and monitor the fulfillment of the Arusha Accords, or they would deteriorate further, in which case it would be "necessary to revise" UNAMIR's mandate or even reconsider its very presence in the country. ${ }^{32}$ UNAMIR was on the agenda daily. A few days later I reported to Prague that "a large part of the discussion ... was devoted to variants of UNAMIR's activities in the country." 33

At the time, the secretary-general presented two alternatives: either, in the case of a cease-fire, to maintain a slightly smaller UNAMIR that would see to its terms being kept, or to pull out the greater part of UNAMIR, leaving only its commander with 200 to 300 soldiers. During the discussion, I was intrigued by the argument of Ned Walker, Ambassador Albright's deputy: "If we were to decide now, the US would be for a withdrawal." I understood clearly: "If we don't decide now, we're deciding to stay in the country," I observed-and that's how the matter ended up, for another few days, at least. ${ }^{34}$

The UNSG promised "a special report" on UNAMIR; it reached us on 21 April, more than two weeks after the slaughter had started. ${ }^{35}$ Yet even this report-unbelievable though it may sound-still saw UNAMIR's main role not in stopping the carnage but in attempting to enforce a cease-fire between the army of the ruling Hutu and the RPF. After the withdrawal of the Belgian contingent and dispensable members of other groups, the number of soldiers and observers in Rwanda had decreased from 2,500 to some 1,700 .

This time around, the UNSG offered three alternatives. One of them, a total withdrawal of UNAMIR, he didn't recommend at all; it was perhaps introduced only for the sake of logical completeness, so to speak. The second repeated one of his alternatives of 14 April (i.e., leave only a small force in the country, now limited to 270 soldiers).

The third suggestion was quite different, however: it was a suggestion to radically beef up UNAMIR, by no fewer than several thousand soldiers, and to equip it with a new mandate, under Chapter 7 of the UN Charter. I am still uncertain where this proposal emerged from, who or what might have inspired the UNSG to face the issue 
in such a radical manner. Did someone's conscience wake up, perhaps? Or was it a foil to prove that nothing really could be done?

Chapter 7? This represented a definite shift. Operations that the UNSC organizes in various countries are run either under Chapter 6 or under Chapter 7 of the UN Charter. Chapter 6 assumes that the international operation takes place in accordance with the wishes of local authorities, for example, on the invitation of the host government. No big problem here. (UNAMIR was originally organized under Chapter 6.) Chapter 7 comes into play in much more complicated situations: the local authorities may not agree with the operation, or perhaps there actually are no effective local authorities, and so on. Given the nature of the situation, Chapter 7 operations are usually more dangerous, and peacekeeping under this chapter requires a more robust mandate and different rules of engagement. Additionally, from the point of view of international law, such operations, begun willy-nilly, amount to interference in the domestic affairs of the "host" country.

Years later, I reread this proposal. It was very good, even earth shattering. If implemented, it would have been the only proposal that could have changed anything. An operation under Chapter 7 could not only have arranged for monitoring some kind of peace (nonexistent in Rwanda, under the circumstances) but also allowed for an intervention in the country, whether or not the country's rulers (whoever they might be) wished it.

The proposal had only two "minor" flaws. First, it would have been absolutely impossible to find "several thousand" additional UNAMIR soldiers. According to his own evidence, the UNSG had personally telephoned dozens and dozens of heads of state and government in search of additional soldiers-to no avail. Salim Ahmed Salim, president of the Organization of African Unity (OAU), tried to recruit soldiers as well, as did President Museveni of Uganda, an RPF ally. And even if the soldiers were found, it would take months before they could be organized and sent, equipment and arms would have to be found somewhere else, and someone would have to arrange for their transport. Meanwhile, the slaughter continued daily.

The second problem was with Chapter 7 itself. At least one delegation was always extremely reluctant to use this measure when a domestic situation within a country was at stake-which decidedly was the case with Rwanda. This delegation always hesitated to allow the international community to intervene in a country over the head of the local government, and was always alert to the possibility of creating a precedent that at some point-who knows? - might be turned against its own authorities. This was the delegation from China, with its UNSC veto power.

The UNSG's report thus didn't satisfy many people. The non-aligned nations would gladly have strengthened UNAMIR; the United States would have preferred a complete pullout. UNSC Resolution 912, which was finally adopted on 21 April, 36 resolved the situation ambivalently. Only the 270 soldiers mentioned in one of the UNSG's alternatives were to stay in the country; the rest were to be withdrawn, but only to somewhere close by, in East Africa, as a sort of over-the-horizon reserve.

It was the worst decision the Security Council could possibly have taken. Not only did we not decide to strengthen UNAMIR, we ended up weakening it to the minimum militarily acceptable (i.e., capable of self-defense) force. Among other things, we thereby handed over to the killers perhaps thousands of civilians whom UNAMIR was still able to protect at the time. Our soldiers in UNAMIR were appalled. General Henri Kwami Anyidoho of Ghana, Dallaire's UNAMIR deputy commander, couldn't understand this decision: "Was the world going to abandon 
Rwanda? Was it because the operation was in a typically developing country or more pointedly on the 'dark continent'?" 37

\section{The Czech Position Evolves}

Meanwhile, my own interventions during Security Council consultations were ever sharper. On 20 April I wrote to Prague, "More alarming information has reached us from Human Rights Watch, according to which 100,000 people have been slaughtered already. Interpreting the warfare exclusively as tribal is terrific oversimplification." 38 I argued even with my friends-such as the otherwise extremely capable and decent Ambassador Emílio Cardenas of Argentina-who in the context of Rwanda used the expression "humanitarian catastrophe." The UNSG talked about a "firestorm of mass killing." A few days later, the UNSC president, New Zealand's Ambassador Colin Keating, received a representative of the French NGO Médécins sans frontières (MSF), who reported that shortly before their meeting, government forces and the Presidential Guard had broken into the MSF hospital in Butare and murdered all its Tutsi personnel, then returned and murdered all the Tutsi patients. $^{39}$

I understood the situation (finally!): this was not a "humanitarian catastrophe," or even simple "killings," no matter how massive; this was the deliberate extermination of one ethnic group. On 25 April, I wrote to Prague,

This is a matter of clear genocide committed by governmental and presidential units of the Hutu against the Tutsi. No matter how one turns the numbers around, there were perhaps 1.2 million Tutsi before the war, of which at least 100,000 have been slaughtered. The regional organization (OAU) takes into account the stability of the country or the legitimacy of its government: it tries to effect a cease-fire, and holds both parties at the same level. Is this not as if we had wanted Hitler to reach a truce with the Jews? (The comparison is not perfect but the proportions coincide.)

And, most importantly, I alerted Prague, our "non-non" group wanted to consult as to whether there might not be some other way for the Security Council to react than by simply pulling out UNAMIR, "of which at this moment only 450 men are left in the country." 40

On the following day we received a letter from Claude Dusaidi, RPF's representative in the UN, titled "Genocide in Rwanda." 41 Dusaidi pointed out that the Rwandan government's goal was not victory over the RPF but, rather, the extermination of the Tutsi. And, among other things, he demanded the creation of a war-crimes tribunal.

At about this time, I called Ambassador José Ayala-Lasso. This Ecuadorian diplomat had been appointed the UN's first high commissioner for human rightscoincidentally, on 5 April 1994, the very day of the plane crash. He had been worried about Rwanda; I urged him to go to the country as soon as he could. In the event, he visited on 11 and 12 May and talked to all sides. Even he, however, in the report published on 19 May, still described Rwanda as "a human rights tragedy," avoiding the word "genocide." 42

\section{The Czech Draft Presidential Statement}

On 28 April, my delegation began a fairly daring battle to get the Security Council, which effectively continued to ignore the slaughter of the Tutsi, to make some meaningful statement. In an interview at the time I pointed out that $80 \%$ of the attention that the Security Council had devoted to Rwanda concentrated on the fate of our 
blue berets and the remaining $20 \%$ on the civil war. We had said nothing about the slaughter, and at a certain point I realized that we would be a laughingstock around the world if we did not finally come out with a statement on this topic. So I prepared a draft Presidential Statement on the issue.

The Security Council issues two principal types of public documents. One is the resolution, which is subject to voting; the other is the presidential statement. Though they are called "presidential," these statements are in fact issued by the entire Security Council. They are not legally binding, and thus don't have the same weight as resolutions; however, precisely because they are not voted on, their adoption requires consensus: all UNSC members must agree to every word of the text.

The Czech draft Presidential Statement ${ }^{43}$ was unusual, intentionally and consciously. We deviated from customary usage in several respects. We took note of information that the Security Council had been receiving from the UNSG, but we also, and specifically, appreciated information received from generally highly regarded NGOs. This was unheard of: on the one hand, we were intimating that the secretary-general had not been informing us sufficiently broadly, and on the other hand (this was more of a technical matter), we were referring to documents that had not been blessed by the UN's document registration system. ${ }^{44}$ Yet we were very attached to the references to NGOs, because our most valuable and most trustworthy information originated with Africa Watch, Amnesty International, the International Committee of the Red Cross, and MSF, whereas the UN Secretariat did not furnish much of value.

Our draft warned the so-called interim (Hutu) government of Rwanda of its responsibility to rein in all military and paramilitary elements responsible for the ongoing brutalities. In particular, however, our draft contained the following formulation: "The Security Council reaffirms that the systematic killing of any ethnic group, with the intent to destroy it in whole or in part, constitutes an act of genocide as defined by the relevant provisions of international law."

"The Security Council," we continued,

points out that genocide cannot be condoned or tolerated, let alone justified, under any circumstances: not by civil war, not by the death of a leader, whatever suspicions surround it, not by past history. The Council further points out that an important body of international law exists which deals with perpetrators of genocide.

As I had expected, we didn't achieve any immediate success, but some reactions still surprised us by their sharpness. I was taken aback, for example, by the reaction of the British ambassador, Sir David Hannay, who observed that such a presidential statement would turn us "into a laughingstock" and that in these matters "we should leave the leading role to the African group." The French ambassador, Jean-Bernard Mérimée, argued in turn that according to his information, brutalities were committed not only by Hutu on Tutsi but also by Tutsi on Hutu. In reaction, I carefully analyzed the sources of our information (after all, the French MSF had only recently met with the president of the Security Council) and why I trusted these organizations, and invited him to elaborate similarly on his information about alleged Tutsi atrocities and to clarify its origin. He never reacted to this invitation. (This was yet another small stone fitting into the mosaic of suspicions I had developed concerning France's policy on Rwanda.)

Ibrahim Gambari, Nigeria's ambassador, then further muddled the outcome of our draft statement-though probably unintentionally, seeing that he was one of the most decent ambassadors on the Security Council, and my good friend. He 
informed us about a meeting the previous day of the African Regional Group in the UN, which dealt with Rwanda. On basis of that meeting, he proposed his own draft presidential statement, which sought a sort of African solution, including, among other things, the involvement of the Central Organ for Conflict Prevention, Management and Resolution that apparently functioned under the umbrella of the OAU. I had never heard of this Central Organ (which in and of itself didn't mean much), but in addition, it didn't seem to have a very successful track record. These Nigerian ideas struck me as a chimera; they would not have led to anything sensible, and, unlike our draft, they didn't even characterize the situation in Rwanda as genocide. ${ }^{45}$

The ensuing discussion combined reactions to both drafts. The effort that informed ours-namely, that the UNSC should finally dare to describe the Rwanda slaughter as genocide-was watered down; those who rejected that designation completely found it easy to focus on the African draft.

As the discussion progressed (still on 28 April), Colin Keating, president of the Security Council for April as ambassador from New Zealand, attempted to blend the two texts so that we could issue some presidential statement at all, of any kind. By this time, more than three weeks had elapsed since the beginning of the holocaust, and hundreds of thousands of people had been massacred. We argued for hours on end over every sentence, every word. And when it appeared that all the negotiations and all the arguments were going nowhere, Colin played his final trump card: his delegation rewrote the draft presidential statement, as it had emerged at that moment, into a draft UNSC resolution.

This was an absolutely brilliant maneuver. Unlike a presidential statement, a resolution didn't require unanimity. And so, if the Security Council was unable to agree on a presidential statement, the New Zealand delegation, supported by other friendly delegations (including, naturally, the Czechs), could present a draft resolution, possibly with even tougher language. Those who didn't like it could vote against it-and at least show their true colors. And even if any of the permanent members ended up vetoing the resolution, this would indicate the unbelievable-that a holder of the UNSC veto power was in agreement with genocide!

A technical comment needs to be made here. Any draft resolution or presidential statement is first issued by the Security Council internally, in blue (as opposed to black) ink. Such drafts are discussed as "texts in blue." The actual document can be issued only twenty-four hours later. Even during these final twenty-four hours, the Security Council (or the co-sponsors of the text) can agree to some final changes, if necessary. This possibility, however, is used quite rarely.

Now, Colin timed his maneuver for the last possible moment. Only two days remained of New Zealand's presidency. Colin came out with his move just before midnight on 28 April. His draft resolution would have got the required twenty-four hours "in blue" by midnight on 29 April-and he would still have time to convene a public, official meeting of the Security Council for 30 April, the last day of New Zealand's presidency, and have this draft voted on.

A draft resolution thus hung like the sword of Damocles over the heads of the hesitant members. Even so, negotiations were very complex. We were already completely exhausted when we fought over the last remaining issue-namely, how to apportion the blame for the continuing catastrophe between the Hutu and the Tutsi. The debate featured two clear-cut opinions: France, for example, wanted to divide the blame "equally," whereas New Zealand, the Czech Republic, and several other delegations saw the carnage as unambiguously the work of the Hutu extremists. 
Battered by the long hours, Security Council members might even have been prepared to accept some not completely repugnant formulation, if only to be able to retire-by now it was long past midnight, in the early hours of 29 April. I don't recall the final formulation we thought we had reached, but when Colin asked whether we could all agree to it, it was quiet around the table. For a long moment it seemed that the negotiations were over. Eventually, though, I couldn't help myself: the text still put too much weight on some spurious guilt of the Tutsi. It was as though the Jews were being responsible for their own extermination by the Nazis. I spoke up-the language still wasn't acceptable to me. Like-minded colleagues, especially from the "non-non" group, sighed in relief: they didn't like the proposed language either. This last skirmish then ended up with language improved even a little further, thanks to the chiseling skills of the British ambassador. "Attacks on defenceless civilians," we ended up agreeing, "have occurred throughout the country"- this formulation was a concession to those who wanted to share out the blame equally, but at least it spoke about "the country" and not about tribal or political "groups." But the sentence continued-“especially in areas under the control of the armed forces of the interim government of Rwanda," that is, the Hutu. So in the end we attributed blame where it belonged.

Not surprisingly, not a word remained about the work of and information from NGOs that the Czech delegation had stressed in our original draft. I wrote to Prague that China and Oman were particularly loath to allow for a precedent of the Security Council's reacting to information from NGOs. ${ }^{46}$

The word "genocide" was not mentioned either. At least an oblique reference to genocide appeared, though, as the statement recalled that "killing of members of an ethnic group with the intention of destroying such a group in whole or in part constitutes a crime punishable under international law." This crime, of course, is the one called genocide-even though the word itself was not used in the text. New Zealand's draft resolution, "in blue," which had been held in reserve, went into the archives, and the presidential statement initiated by my delegation was accepted, albeit rather too watered down for our taste. ${ }^{47}$

The Czech presidential statement initiative that New Zealand, in the president's chair, crocheted through the negotiations was our most intensive effort to influence the Security Council's deliberations on Rwanda. It was also the only occasion during our two-year stint on the Security Council when the Czech delegation by itself initiated a text of any document. Even though we did not succeed, or at least not without the text's being greatly watered down, I consider this to have been one of the most important of our efforts in the Security Council. It is not very well known, because the Security Council holds its consultations behind closed doors and its "internal matters" only seep out. This draft, and Czech public statements at formal Security Council sessions, presented the overall view of our country, one that eventually received broad international recognition.

\section{Genocide-The Expression}

And so we found out yet again, the hard way, while discussing this presidential statement, that the word "genocide" was taboo in the Security Council. Nobody used it publicly, however clear it was that this was exactly what was taking place. Nobody used it because using it would have legal repercussions. Genocide is forbidden by the international Convention on the Prevention and Punishment of the Crime of Genocide (UNCG) of 1948; and, in addition, the UNCG confers a duty to 
punish génocidaires. The United States, always weighing ever so carefully the legal implications of any step, did not intend, or did not wish, to act on this duty. Its representatives argued that in the case of Rwanda one could at most talk about "acts of genocide," but not about genocide as such. I have never understood the distinction between the two.

This US position evoked a certain echo in Czech diplomacy as well. During a nighttime ride through the streets of New York, Alexandr ("Sasha") Vondra, at the time first deputy to Foreign Minister Jozef Zieleniec, suggested that I moderate my statements concerning Rwanda. He had just arrived from Washington and was perhaps conveying the reaction of the US administration. I simply opened the daily paper and pointed out one article after another on the ongoing atrocities. The newspapers had a clear picture of the situation, and so did I. Sasha didn't insist, and I moderated nothing.

On the one hand, the Security Council's inability to come to grips with the situation was caused by the blinders worn by some countries had (the American "acts of genocide," the difficulties that some Third World countries had in view of their own policies toward minorities). On the other hand, for many of us, the Rwanda events fell so dramatically out of the normal curve of nations' possible behaviors that one instinctively refused to believe them. Fifty years after the term "genocide" was first introduced into the glossary of international politics, as a consequence of the Shoah, and twenty years after the holocaust launched by the Khmer Rouge, it was hard to admit that we were dealing not with a historical category but with an acutely contemporary one, not with a one-off event but with a recurring one.

Apart from that, I detected a soupçon in some of the remarks, along the lines of It's easy for you Czechs to point fingers when you are not obligated to deal with any consequences. Are you perhaps going to send your soldiers to Rwanda? This, of course, was a cheap argument; if it were true, it would imply that smaller countries have no business at all sitting around the Security Council table. And, in addition, while the Czech Republic had no soldiers in Rwanda, it had deployed them in a long list of other difficult and dangerous places; if we had none in Rwanda, it was more a result of the random selection of where our soldiers went than of a deliberate policy of avoiding that country.

The fact that for weeks on end nobody publicly used the word "genocide" was, in my view, symptomatic of the complete collapse of the UN Secretariat's responsibility and of the Security Council's impotence. In the end, I became the first official to use the expression publicly, in a public session of the UN Security Council. (During informal consultations, behind closed doors, several of us had been using the term for some time now.)

The opportunity to make the point in public arose on 5 May 1994. A UNSC session had been convened to deal with Mozambique, but I managed to insert a reference to Rwanda into my remarks: "Different countries of the cone of Africa south of the Equator," I said,

are facing an exceptionally broad array of political circumstances at this moment. On the one end of the spectrum, there is the hell of Rwanda. My delegation is appalled by the situation in that country and has been shocked by the fact that neither the Security Council nor the UN Secretariat has so far managed to describe the massacres in Rwanda with the only word that fits them-namely, genocide. ${ }^{48}$

And the word was out in public, for what it was worth. 


\section{Resolution 918/1994}

The presidential statement of 30 April was better than nothing, but the Security Council still hadn't started working on a resolution that would not only comment on the Rwanda massacres but also do something about them. Eventually, such a resolution was adopted-but not until May. The first public, official, formal meeting on Rwanda took place only on 16 May. On that occasion, I started my own statement forcefully: "The crocodiles in the Kagera river and the vultures over Rwanda have seldom had it so good." The ambassador of Djibouti, sitting to my left, snickered.

They are feeding on the bodies of thousands upon thousands of children, women, hundreds of whom were pregnant, and men who have been hacked to death during the past six weeks by what has turned out to be a most vicious regime.

The massacres include 4,000 killed in Kibeho; 5,500 butchered in Cyahinda; 800 assassinated in Kiziguru; 500 slain in Rukira; 2,500 slaughtered in Kibungo; another 4,000 have been murdered in Shangi, a parish in the Cyangugu prefecture, and 2,000 in Mibirizi, also in Cyangugu. This is the same Cyangugu where for several weeks now, many thousands have apparently been trapped for weeks on end in a stadium without any relief. Surely one wonders whether the dead are not better off than the living.

By now, the Djibouti ambassador had long stopped snickering.

I hadn't finished.

So we have some 200,000 Tutsi lives lost [this was the number offered by the secretarygeneral], out of a total population of about one million-20 per cent of all of Rwanda's Tutsi. Each one of us can figure out how many lives such a percentage would represent in his own country, for his own people. This situation is being described as a humanitarian crisis as though it were a famine or perhaps a natural disaster. In the view of my delegation, the proper description is-genocide. ${ }^{49}$

It was a chilling presentation, perhaps the strongest I ever delivered in a public session of the Security Council. For one thing, it was the first public presentation on Rwanda (consultations having been closed to the public) where I had the opportunity to present our overall evaluation of the situation. I spoke about the slaughter being executed by the Hutu on the Tutsi and about the impropriety of trying to hypothetically "spread the blame around," an approach for which there was no evidence. (This was an oblique attack especially against the occasional arguments of France.) I spoke about the conceptual difference one must make between victims of war, albeit a civil war, and one-sided sacrifices of civilians far behind the front line. On the other hand, I refused any "collective guilt" of the Hutu and pointed a finger specifically at the butchers of the Presidential Guard and government military and gendarmerie units, all of which had been linked with former president Habyarimana. I also drew attention to the inflammatory Mille Collines radio station.

In conclusion, I reviewed the evolution of the Security Council's approach over the previous six weeks: first the absolute shock, when we hesitated even to believe the overall horror of the ongoing massacres; then the worry for our own units, after the ten Belgians lost their lives; then the courage of UNAMIR, which, in unbelievably uneven circumstances, managed to save at least the bare lives of at least a few tens of thousands of desperate souls in Kigali. I saluted their courage, as well as the NGOs, "which have done so much to apprise us of the true nature of the conflicts in Rwanda." This, in turn, was an oblique criticism of the Secretariat for not informing the Security Council well enough. 
At this meeting, the Security Council approved Resolution 918/1994 (co-sponsored by the Czech delegation), which directed the return of UN units to Rwanda. ${ }^{50}$ After six weeks of horrors, we had finally managed to decide to boost UNAMIR's troop strength up to 5,500 and to strengthen its mandate. Even that was not easy: as I wrote to Prague, ${ }^{51}$ the Security Council found it taxing to deal with the views of the United States, who were very wary of the operation's failing. They feared that in a situation where neither party agreed with sending UNAMIR in and neither was prepared to abide by a cease-fire, the danger was dramatically increasing that UNAMIR would find itself in the midst of a bloody conflict, as in Somalia. And so, while the United States were prepared to contribute up to one-third of the costs of this operation, the perspective of possible victims decreased the chances that the US Congress would agree to this financing.

Disregarding the opposition of one of its members, namely Rwanda itself, the Security Council decided to impose an arms embargo on the country. The resolution was voted on in parts-an exceptional measure, used very seldom, in situations when this or that member objects to just this or that paragraph of the draft. The representative of Rwanda objected specifically to Part B, which imposed the arms embargo.

That the Rwandan (Hutu) government would even take part in this session, after six weeks of incessant slaughter, bordered on the grotesque. It was attended by the Minister of Foreign Affairs and International Cooperation (!) of the murderous Hutu "interim government," a certain Jérome Bicamumpaka. Colin Keating, New Zealand's ambassador, subjected him to scathing sarcasm and expressed his astonishment that we had even allowed him to take up Rwanda's place on the Security Council.52 The representative of Rwanda, said Keating, "does not represent a State. He has no legitimacy and is merely the mouthpiece of a faction." (The representative in question is now facing responsibility for his part in the genocide at the Arusha international tribunal.)

\section{The Hurricane Abates}

A few days later, the secretary-general sent his people to Rwanda to prepare the new phase of UNAMIR's activity. (The delegation consisted of his deputy, Iqbal Riza of Pakistan, and Canadian Major-General J. Maurice Baril, Kofi Annan's military advisor for PKOs.) The Hutu regime in Kigali, meanwhile, was teetering on the brink, but it still had the strength to massacre people. The regime still controlled the capital, but its airport was now under RPF control. (At about this time, SRSG Jacques-Roger Booh-Booh pulled out of Rwanda. He was to visit several African countries and request their good offices in resolving the Rwanda conflict. One might say, none too soon! More recently, he has apparently given testimony at the International Criminal Tribunal for Rwanda-in defense of the alleged génocidaires.)

Toward the end of May, the RPF and the Rwandan government forces (RGF) started talking, under the auspices of the UN, for the first time since 6 April, when the slaughter commenced. It still wasn't over, though, and during their first meeting, the RPF demanded an end to the massacres. The RGF allegedly asked their units and the militias to be "more tolerant" of the Tutsi, but as late as 28 May they nevertheless massacred some 500 Tutsi who had sought shelter in a cloister north of Kigali.

The UNSG issued another report on Rwanda on 31 May. No longer could he be mealy-mouthed. Here he confirmed our own information about the breadth and 
depth of the cataclysm that had engulfed Rwanda: "There can be little doubt that it constitutes genocide," he confirmed, more than three weeks after I had first publicly used this expression in the Security Council.53 "My delegation," I said subsequently in a Security Council meeting, "is troubled that it has taken so long for the Secretary to use this description in his reports, on which the Security Council bases its work heavily." 54

\section{Dénouement}

In June 1994, three months after it had first swept the country, the tsunami of murders finally began to ebb. The greatest merit for this goes to the RPF, which had continued its civil-war offensive (and seldom has a war been more civil than here) and was crushing the Hutu forces. One might say that throughout the country the RPF was liberating the miserable remnants of Tutsi who had not been murdered; but, in fact, day after day they were faced with further and further evidence of the terror of extremist Hutu.

In these circumstances, France made an offer to the Security Council: it would undertake its own operation, allegedly to alleviate the humanitarian situation further by attempting to protect the endangered civilian population. It wasn't clear why France had suddenly become so solicitous, and various reservations and objections were voiced both in the Security Council and beyond. These doubts, rather exceptionally, found expression even during the vote on the French draft resolution, from which Brazil, China, New Zealand, Nigeria, and Pakistan eventually abstained. In my temporary absence, the Czech delegation didn't figure that anything could go wrong with the French initiative, and ended up supporting Resolution 929/1994, which authorized Operation Turquoise. ${ }^{55}$

Only after some time did we understand what France had been up to. It became clear that France was very anxious about the unstoppable advance of the RPF and greatly feared for its protégés among the Hutu leadership. Operation Turquoise thus, in essence, blasted the way for the Hutu génocidaires to escape from the country, mainly to the neighboring Democratic Republic of Congo (DRC). A number of French soldiers were apparently shocked when they realized, upon arriving in the country, who it was they were supposed to protect.

The murders didn't end even during this operation, though. In the south of the country-for example, in the forests and caves of the Bisesero region in Kibuya province-Tutsi had for weeks and months been fighting and resisting Hutu inroads, in an uneven struggle, without arms and eventually without food. ${ }^{56}$ (Bisesero is today one of the main symbols of Tutsi resistance, as I witnessed during my 2004 visit to the Kigali genocide memorial on the occasion of the tenth anniversary of the holocaust.) After the French arrived, multitudes of Tutsi fell into a trap: believing that they would now be safe, many descended from the mountains, only to be murdered by the Hutu, as late as June 1994. Only about 1,000 people survived in the area, where some 50,000 had originally sought refuge. One cannot say that this was France's intention; but there is no doubt that they went to Rwanda to protect the Hutu, not out of any great regard for the Tutsi.

A minor concluding comment: in July, Ambassador Bizimana, representative of the Hutu, made his last appearance in the Security Council. Long before then, he had stopped speaking up in informal consultations, apparently on the advice of the French themselves. Now he disappeared from New York, along with the contents of his delegation's bank account. ${ }^{57}$ For a while, Rwanda's seat fell vacant. On 
2 September 1994, it was taken up by Ambassador Manzi Bakuramutsa, representing the new Tutsi-led government.

\section{What about the génocidaires?}

The RPF ended up defeating the Hutu militarily. The Hutu administration-the so-called interim government, the government's military, the Interahamwe, various militias, Radio-Télévision Libre des Mille Collines-were all escaping the country. Masses of ordinary people were also crossing the borders to Tanzania and the DRC. I watched on television the slowly moving masses with their cattle-drawn wagons. They did not give the impression that their lives were threatened, that they were facing a clear and present danger. This is not to say that murderers among them had nothing to fear, nor to exclude the possibility that a great proportion of Hutu, perhaps even the majority, took part or were forced to take part in the slaughter. The TV images, however, left the impression of an orderly exodus, an exodus probably organized by the Hutu extremist wing. The days and weeks that followed only confirmed this impression.

The Hutu exodus amounted to an export of Rwanda's problems. Refugee camps in neighboring countries turned into ulcers on the body of Central Africa. There were concerns for the refugees themselves, that is, for their living conditions, for the possibility of return, and so on; in addition, though, the camps were under the strict control of the Hutu militias, who forcibly prevented from returning even those who wanted to go back, and could have gone back, to Rwanda. The militias, defeated in the civil war, continued to spread disturbances from beyond the borders. Based in the refugee camps, they "continue to spew hatred against ... their intended victims who got away. They preach hatred, operate incendiary radio stations, keep an iron hold over the rest of the camp population, prevent ordinary people from going back to their homes and fields, throttle efforts of humanitarian operations-indeed, they are possibly preparing for a renewal of the war," as I argued in the Security Council in November 1994, months after a degree of order had been established in Rwanda itself. 58

For the new Rwandan government, now headed by RPF politicians, these refugee camps represented a constant security threat. Their chieftains spread their toxic influence throughout Central Africa, and one can say that a number of the area's problems since, especially in the DRC and in Burundi, stem from unsettled accounts with the perpetrators of the Rwandan Genocide and the consequent security concerns of the Tutsi government in Rwanda.

One task remained for the Security Council: to arrange for the settling of accounts. In early June, when even the secretary-general had come around to describe the events in Rwanda as genocide, I said in the Security Council that one doesn't use the word "holocaust" lightly.

But today, as we commemorate the 50th anniversary of D-Day, we reflect upon the Second World War as a war directed against a regime which became anathema to the civilized world precisely because of it having unleashed a holocaust. The regime in Rwanda has been attempting to do something similar-with machetes instead of gas chambers; with the notorious interahamwe, comparable to the SS; with [specified political parties] comparable to the Nazi party. It was precisely to forestall the re-emergence of such regimes that this Organization, the United Nations, was created almost 50 years ago.

Genocide is a crime, and, to state the obvious, where there is a crime there are criminals. ${ }^{59}$ 
Three weeks later I elaborated,

The conflict in Rwanda has led to massive and systematic violations of a whole series of international agreements and conventions-including, to name just a few, the Universal Declaration of Human Rights, the International Convention on the Elimination of All Forms of Racial Discrimination, the Convention on the Prevention and Punishment of the Crime of Genocide, the Convention against Torture and Other Cruel, Inhuman or Degrading Treatment or Punishment, the Convention on the Rights of the Child, and-it goes almost without saying-of international humanitarian law ... Provisions of the Convention on the Non-Applicability of Statutory Limitations to War Crimes and Crimes against Humanity may well be applicable to the circumstances of Rwanda. ${ }^{60}$

How to deal with the criminals? Their crimes violated the basic principles of international law. The logic of the matter would require that the Security Council react in a way parallel to its reaction to the conflicts in the former Yugoslavia and that it create another ad hoc tribunal-something RPF's Claude Dusaidi had, after all, called for at the end of April. And this is exactly what the Security Council decided to do, in its Resolution 955/1994. ${ }^{61}$ The lion's share of the merit for reaching this decision-as, indeed, in so many other aspects of resolving the Rwandan catastrophe-goes to the New Zealand delegation. ${ }^{62}$

These ad hoc tribunals were the only possibility available for international settlement of war crimes or crimes against humanity, given that any project of an overall, generic international criminal tribunal was at the time still in its infancy. 63 I pointed this out in the Security Council. The decision to establish a specific tribunal for Rwanda, I observed, "might signify a breakthrough in creating mechanisms that would impose international criminal law ... New concepts of international criminal law have been developed-war crimes, crimes against humanity, genocide, and so on-while rules of procedure have remained quite underdeveloped since the Nuremberg trial." 64

Punishment is one thing, justice is another, and national reconciliation is something else again. "The Tribunal," I said in the Security Council,

might become a vehicle of justice, but it is hardly designed as a vehicle of reconciliation. Justice treats criminals whether or not they see the error of their ways; but reconciliation is much more complicated, and is certainly impossible until and unless the criminals repent and show remorse. Only then can they even beg their victims for forgiveness, and only then can reconciliation possibly be attained. ${ }^{65}$

Yet remorse, regrets, never mind repentance, were clearly not something one could expect from the Hutu génocidaires-certainly not from those who had left the country and were mobilizing against the Tutsi from across the borders.

\section{In Conclusion}

The Rwandan Genocide took place in 1994, but it is still a live matter in Central Africa. The flight of the Hutu génocidaires to neighboring countries broadcast the seeds of Rwanda's catastrophe far and wide. Neighboring Burundi, which I visited twice during my tenure on the UNSC, ${ }^{6} 6$ is engulfed in a Tutsi-Hutu rivalry as well. ${ }^{67}$ The eastern part of the DRC has turned into a theater of an unclear and terrifically bloody war that over time has involved several other African countries, from Uganda to Angola and definitely including Rwanda. Permanent concerns for the security of their fellows have led current Rwandan leaders to hard-to-understand adventures in the DRC. One talks about a "thirty-year war" in Africa; one talks 
about millions of dead victims, of which Rwanda itself lost perhaps 800,000 (we will never know the exact number). One can say without stretching the point that some of the roots of Central Africa's current warfare grow out of the carnage in Rwanda. Who sows the wind, reaps a whirlwind.

The United Nations has reflected on its role in this catastrophe. After he was elected UN Secretary General, Kofi Annan established a committee that analyzed in detail the entire role of the organization, its Secretariat, and the Security Council. ${ }^{68}$

Important participating countries have also examined their positions and policies. During his visit to Rwanda, US President Bill Clinton expressed regret for his government's policy during the genocide. ${ }^{69}$ Senate hearings took place in France, and Belgian parliamentarians also examined their country's role. In her memoirs, Madeleine Albright discusses her lack of information and the incorrect US evaluation of the situation, which attempted to fit Rwanda into a template derived from elsewhere. She sums up the US role thus: "The lessons we thought we had just learned in Somalia simply did not apply in Rwanda. Somalia was something close to anarchy. Rwanda was planned murder. Somalia counseled caution; Rwanda demanded action."70

The position of the Czech Republic in this crisis was a principled one, and we followed it as best we knew how. During the 1930s, British Prime Minister Neville Chamberlain didn't want to commit his country to the cause of Czechoslovakia (threatened at the time by Nazi Germany), "a small far-away country which no one knows." For us, Rwanda, too, was a small far-away country we hadn't known much about; but it was precisely our historical experience with the Western diplomacy of the 1930s that obligated us to act differently.

Czech positions derived from one of the key principles of Czech foreign policyrespect for human rights. New Zealand was even more active than we were, probably because of their much longer diplomatic experience and the legal mind of Colin Keating, their superb ambassador and former justice minister. But even years later, the role of the Czech Republic and Czech statements and positions in the bog of those months look good. Our standpoints, our formulations, our initiatives, are to this day quoted in most publications that deal with the role of the Security Council during that period. ${ }^{71} \mathrm{We}$ are remembered in Rwanda, and whenever diplomats from the Czech Embassy in Kenya visit the country, the role of the Czech Republic on the UN Security Council in 1994 is recalled with gratitude.

For me personally, Rwanda was a key formative personal, diplomatic, and political experience. It strengthened my realization of how indispensable it is to act in accordance with one's own internal moral compass, in accordance with the basic principles one adheres to, even if they cannot always be defined simply or briefly. Diplomatically, since Rwanda (and since the Srebrenica carnage that the Security Council dealt with in 1995), I have been fully conscious of the need to stand up against any danger of extermination of any people, anywhere. And politically, the red line beyond which one simply cannot make further compromises became even clearer.

\section{Notes}

1. An earlier version of this article appeared in the Czech journal Mezinárodní vztahy, no. 3 (2004): 45-65.

2. The background of the situation in Rwanda, the civil war, the role of the UN, and the genocide is covered in an extensive and ever-expanding list of sources, each containing additional references. Ryszard Kapuściński, Heban [Ebony] (Warsaw: Czytelnik, 2003), 174-92, serves as a possible brief introduction. (Alas, I am not aware of an English trans- 
lation.) Rwanda itself is covered in, e.g., Gérard Prunier, The Rwanda Crisis: History of a Genocide (London: Hurst, 2002). Michael Barnett, Eyewitness to a Genocide: The United States and Rwanda (Ithaca, NY: Cornell University Press, 2002), is a detailed work about the US involvement. Linda R. Melvern, A People Betrayed: The Role of the West in Rwanda's Genocide, 2nd ed. (London: Zed Books, 2009), is exceptional. (The citations that follow below are from the book's first edition, however.) Alison des Forges, "Leave None to Tell the Story": Genocide in Rwanda (New York: Human Rights Watch, 1999), may contain the most extensive non-UN documentation.

3. All official UN documents on this matter for the period in question are contained in an extensive collection, The United Nations and Rwanda, 1993-1996 (New York: United Nations, 1996). The text of this resolution is found on pages 221-31.

4. In European African studies, these two peoples are usually discussed as "tribes," though differences between them are really not the same as those between actual tribes. These distinctions, however, are not the subject of this essay. Kapuściński, Heban, explains the matter clearly.

5. UN and Rwanda, 170-201.

6. UN and Rwanda, 251-52.

7. Technically, PDD-25 was not issued until 3 May 1994, but US diplomats followed its guidelines for months before that. Its actual text is confidential, but a summary and discussion of it can be found on the Internet through the Federation of American Scientists, http://www.fas.org/irp/offdocs/pdd25.htm (accessed 9 July 2010). See Barnett, Eyewitness to a Genocide, 139, for a discussion of its influence on US decision making.

8. Madeleine Albright, Madame Secretary: A Memoir (New York: Miramax Books, 2003), 147.

9. Dallaire has written about his tragic Rwandan experience in Roméo Dallaire, Shake Hands with the Devil: The Failure of Humanity in Rwanda (Toronto: Random House Canada, 2003).

10. All statements are recorded in the provisional verbatim record of the 3326th meeting of the UN Security Council, UN Doc. S/PV.3326, http://www.un.org/Docs/journal/asp/ ws.asp?m=S/PV.3326 (accessed 28 June 2010). (Within the UN document numbering system, "S" indicates a UNSC document, "PV" stands for "provisional verbatim record"in fact, there are no others-and 3326 is the consecutive number of the UNSC meeting in question.)

11. The Czech Republic's Permanent Mission to the UN sent almost daily summaries of its work to Prague and other interested Czech embassies around the world. These were not classified, and I therefore quote them freely. Eventually they were formatted with the consecutive number for the given year, a file number, and a date. I quote here from Summary 2/1994, file No.1016/93 [sic], 4/1/94. All translations into English are my own.

12. The text "Political Situation in Rwanda" was appended, unnumbered, to a summary sent to Prague. UN and Rwanda contains various documents from various sources, but not documents from the RPF.

13. I have a copy of this telegram in my archive but am not sure whether it was ever published in its entirety. This telegram, too, is missing from the UN and Rwanda sourcebook. The telegram itself and the background to the information it contains are extensively treated in L.R. Melvern, A People Betrayed: The Role of the West in Rwanda's Genocide (London: Zed Books, 2000), 91-92.

14. I never understood the role of Marrack Goulding, at the time under-secretary general for political affairs. He was bound to play an important role in the flow of information, but his book Peacemonger (London: John Murray, 2002), which deals with a number of PKOs, is deafeningly silent about Rwanda.

15. UN and Rwanda, 31 .

16. UN and Rwanda, 32 .

17. This little skirmish of mine with the secretary-general intrigued a couple of young Danish journalists, who covered it extensively at the time: see, e.g., Martin Burcharth, "Tjekken der taler Boutros-Ghali imod," Information [Copenhagen], 7-8 December 1996. 
18. I have some of these reports in my archive, but not the one dealing with the critical date.

19. For Gharekhan's recollections of the Rwanda developments see Chinmaya Gharekhan, The Horseshoe Table (New Delhi: Pearson Longman, 2006), 236-56.

20. Report of the Independent Inquiry into the Actions of the United Nations during the 1994 Genocide in Rwanda (New York: United Nations, 1999), 26.

21. Summary No. 58/94, file no. 2424/94, 7/4/94.

22. UN and Rwanda, 254-55.

23. Summary No. 59/94, file no. 2437/94, 8/4/94.

24. This was true not only for the first few days but at least for the first weeks. "During the critical days between April 15 and 22," Albright writes, "State Department spokesman Michael McCurry received only one question about Rwanda in his daily press briefings, and that concerned the safety of UN peacekeepers." Albright, Madame Secretary, 154.

25. Technically, Belgium had been a trustee of Rwanda. After World War I, the League of Nations entrusted the former German colony of Ruanda-Urundi to Belgium; Belgian administration lasted until 1962, when two independent countries, Rwanda and Burundi, emerged on this territory.

26. At the time I hadn't yet come to understand that these arguments amounted to a delicate maneuver to bless the Security Council's debate over apparent "domestic" problems. If a domestic problem is such that the number of emigrants and refugees may jeopardize a neighboring country, this is a good enough technical reason for the Security Council to deal with it.

27. Summary No. 60/94, file no. $2438 / 94,10 / 4 / 94$.

28. Summary No. 61/94, file no. 2469/94, 11/4/94.

29. Frank Smyth, "French Guns, Rwandan Blood," New York Times, 14 April 1994.

30. Frank Smyth, Arming Rwanda: The Arms Trade and Human Rights Abuses in the Rwandan War (New York: Human Rights Watch, 1994). Smyth's report was published in January.

31. Des Forges, "Leave None to Tell the Story," 639.

32. Summary No. 61/94, file no. 2469/94, 11/4/94.

33. Summary No. 65/94, file no. 2546/94, 16/4/94.

34. On 15 April, the US delegation received instructions to inform the Security Council that the US favored "full, orderly withdrawal of all UNAMIR personnel as soon as possible." The instruction continued, "Our opposition to retaining a UNAMIR presence in Rwanda is firm. It is based on our conviction that the Security Council has an obligation to ensure that peacekeeping operations are viable ... and that UN peacekeeping personnel are not placed or retained, knowingly, in an untenable situation.” Albright, Madame Secretary, 150.

35. UN and Rwanda, 262-65. The document itself, S/1994/470, is dated 20 April, but it reached the Security Council one day later.

36. UN and Rwanda, 268-69.

37. Ibrahim A. Gambari, "Genocide in Rwanda: Shame on the World," review of Henri Kwami Anyidoho, Guns over Kigali: The Rwandese Civil War-1994 (Accra: Woeli, 1994), West Africa Magazine, date unknown. Gambari was at that time Nigeria's ambassador to the UNSC. I have his review only in manuscript.

38. Summary No. 69/94, file no. 2603/94, 20/4/94.

39. Summary No. $72 / 94$, file no. $2657 / 94,25 / 4 / 94$.

40. Ibid.

41. Attached to Summary No. 73/94, file no. 2674/94, 26/4/94.

42. See document E/CN.4/S3/3 in $U N$ and Rwanda, 285-90.

43. This draft statement was never officially published; it remained a working document. The text itself is reproduced in the Appendix to this essay. It was made available to participants at a May 2004 conference on the tenth anniversary of the Rwandan Genocide, organized in London by Never Again and the Imperial War Museum. That was the only occasion I am aware of when it was distributed in its original English beyond the confines of the Security Council. 
44. The Security Council deals with thousands of documents issued by this or that international organization. In order to be referred to, these documents must first find their way into the UN's "registration system." Usually this is not a problem and is done routinely, at the request of some country, for example. The NGO documents we referred to had not, however, found their way into this registration base, and it would have been difficult to arrange for this to occur.

45. For Ambassador Gambari's recollection of the Rwanda debates see Ibrahim A. Gambari, "An African Perspective," in The UN Security Council: From the Cold War to the 21st Century, ed. David Malone, 512-20 (Boulder, CO: Lynn Rienner, 2004).

46. Summary No. 76/94, file no. 2721/94, 29/4/94.

47. For the text of the presidential statement as it was eventually agreed on see $U N$ and Rwanda, 271-72.

48. UN Doc. S/PV.3375, 8.

49. UN Doc. S/PV.3377, 15-16.

50. UN and Rwanda, 282-84.

51. Summary No. $85 / 94$, file no. 2950/94, 17/5/94.

52. UN Doc. S/PV.3377, 11.

53. For the entire UNSG report see $U N$ and Rwanda, 290-97. The quoted passage is on page 296.

54. UN Doc. S/PV.3388, 3.

55. UN and Rwanda, 308-9.

56. Des Forges, "Leave None to Tell the Story," 216-20.

57. For information about Bizimana's current life in Alabama see David L. Bosco, "Rwanda's ex-U.N. ambassador, who vanished after genocide, resurfaces in Alabama," Washington Post, 4 April 2010, http://www.washingtonpost.com/wp-dyn/content/article/2010/04/02/ AR2010040201517.html (accessed 29 June 2010).

58. UN Doc. S/PV.3453, 7.

59. UN Doc. S/PV.3388, 3-4.

60. UN Doc. S/PV.3400, 4.

61. UN and Rwanda, 387-94, including the tribunal's statute.

62. For Colin Keating's recollections of the Rwanda events, with his evaluation of lessons to be learned, see Colin Keating, "An Insider's Account" in The UN Security Council: From the Cold War to the 21st Century, ed. David Malone, 500-511 (Boulder, CO: Lynn Rienner, 2004).

63. The statute of the International Criminal Court was signed only in June 1998, in Rome.

64. UN Doc. S/PV.3453, 7.

65. Ibid.

66. For a report from the August 1994 visit see UN Doc. S/1994/1039 (9 September 1994); for a report from the February 1995 visit see UN Doc. S/1995/163 (28 February 1995). During this second trip, the UNSC delegation also visited Rwanda; see UN Doc. S/1995/ 164 (28 February 1995).

67. I spoke on Burundi in the UNSC on 28 August 1995; see UN Doc. S/PV.3571, 4-5.

68. See Report of the Independent Inquiry.

69. Clinton apologized, but, as has since become known, his administration was much better informed throughout the period than he or even Madeleine Albright let on. See William Ferroggiaro, ed., The US and the Genocide in Rwanda 1994-Evidence of Inaction: A National Security Archive Briefing Book (Washington, DC: National Security Archive, 2001), http://www.gwu.edu/ nsarchiv/NSAEBB/NSAEBB53/press.html (accessed 29 June 2010) for declassified documents from the National Security Archive; see also Samantha Powers, "Bystander to Genocide: Why the US Let the Rwandan Tragedy Happen," Atlantic Monthly, September 2001.

70. Albright, Madame Secretary, 154.

71. See, e.g., Des Forges, "Leave None to Tell the Story," 638-39; Melvern, A People Betrayed, 152; and Barnett, Eyewitness to a Genocide, 134, as well as references derived from these sources. 


\section{Appendix: Draft Presidential Statement on Rwanda, Proposed by the Czech Delegation to the UNSC on 28 April 1994}

The Security Council is absolutely appalled and horrified over continuing reports of indiscriminate slaughter of innocent civilians in Kigali and various other localities in Rwanda. It notes that according to reliable reports, transmitted to the Council by the Secretary-General in his Special Report (S/1994/470), the current wave of killings was started by unruly members of the Presidential Guard, joined by elements of the Rwandese Government Forces (RGF), over which the interim Government, established on April 8, had failed to establish its authority. Unruly RGF soldiers were also responsible for the brutal murders of Mrs. Agathe Uwilingiyimana, Prime Minister, and several other ministers, of the provisional Government that stemmed from the initial implementation of the Arusha Accords, as well as for the deaths of 10 members of the Belgian contingent serving with UNAMIR.

In addition to information available from the Secretary-General, the Security Council has considered information available from well-respected NGOs. All this information points to one thing: the horrors of Rwanda's killing fields have few precedents in the recent history of the world. The Security Council reaffirms that the systematic killing of any ethnic group, with intent to destroy it in whole or in part constitutes an act of genocide as defined by relevant provisions of international law.

The Security Council points out that genocide cannot be condoned or tolerated, let alone justified, under any circumstances: not by civil war, not by the death of a leader, whatever suspicions surround it, not by past history. The Council further points out that an important body of international law exists that deals with perpetrators of genocide.

The Security Council warns the interim Government of Rwanda of the responsibility it bears for immediately reining in and disciplining all elements of the RGF and of the Presidential Guards responsible for the brutalities. The Council calls upon the interim Government of Rwanda to assure that any group, organization, movement, militia or individual under its control should cease and desist from all acts of genocide against any part of the population of Rwanda. The Council also calls upon the interim Government of Rwanda to investigate all acts of genocide and to severely punish those responsible for their commission. The Council furthermore expresses its hope that forces that are currently engaging the RGF and the Presidential Guard will not resort to comparable countermeasures. 